\title{
Microstructural Control of the Interface Layer for Strength Enhancement of Dissimilar Al/Cu Joints via Ni Addition during TIG Arc Brazing
}

\author{
Hiroki S. Furuya ${ }^{1}$ D , Sakiko Yabu ${ }^{1}$, Yutaka S. Sato ${ }^{1, *(D)}$ and Hiroyuki Kokawa ${ }^{1,2}$ \\ 1 Department of Materials Processing, Graduate School of Engineering, Tohoku University, \\ 6-6-02 Aramaki-aza-Aoba, Aoba-ku, Sendai 980-8579, Japan; hiroki.furuya.p7@gmail.com (H.S.F.); \\ s6.plumchai@gmail.com (S.Y.); kokawa@tohoku.ac.jp (H.K.) \\ 2 Shanghai Key Laboratory of Materials Laser Processing and Modification, School of Materials Science and \\ Engineering, Shanghai Jiao Tong University, Shanghai 200240, China \\ * Correspondence: ytksato@material.tohoku.ac.jp; Tel.: +81-22-795-7352
}

check for updates

Citation: Furuya, H.S.; Yabu, S.; Sato, Y.S.; Kokawa, H. Microstructural Control of the Interface Layer for Strength Enhancement of Dissimilar $\mathrm{Al} / \mathrm{Cu}$ Joints via Ni Addition during TIG Arc Brazing. Metals 2021, 11, 491. https://doi.org/10.3390/ met11030491

Academic Editor: António Bastos Pereira

Received: 24 February 2021

Accepted: 12 March 2021

Published: 16 March 2021

Publisher's Note: MDPI stays neutral with regard to jurisdictional claims in published maps and institutional affiliations.

Copyright: (c) 2021 by the authors. Licensee MDPI, Basel, Switzerland. This article is an open access article distributed under the terms and conditions of the Creative Commons Attribution (CC BY) license (https:/ / creativecommons.org/licenses/by/ $4.0 /)$.

\begin{abstract}
Dissimilar metal joining between $\mathrm{Al}$ and $\mathrm{Cu}$ is effective for reducing the weight and cost of electrical components. In this study, dissimilar lap joining of pure $\mathrm{Al}$ to pure $\mathrm{Cu}$ with an $\mathrm{Al}-\mathrm{Ni}$ filler material was conducted using tungsten inert gas (TIG) arc brazing, and the effect of Ni on the joint strength associated with the microstructure of the intermetallic compound (IMC) layer at the dissimilar interface was examined. The addition of Ni effectively increased the interfacial strength of the joints. Regardless of the addition of $\mathrm{Ni}$, the joints fractured in the thick $\mathrm{Al}_{2} \mathrm{Cu}$ layer formed at the $\mathrm{Al} / \mathrm{Cu}$ interface. However, the $\mathrm{Ni}$ addition reduced the thickness of the IMC layer and led to the formation of $\mathrm{Al}_{7} \mathrm{Cu}_{4} \mathrm{Ni}$ particles in the weakest $\mathrm{Al}_{2} \mathrm{Cu}$ layer. Both the thickness reduction and reinforcing $\mathrm{Al}_{7} \mathrm{Cu}_{4} \mathrm{Ni}$ particle formation are thought to contribute to the increase in joint strength of the $\mathrm{Al} / \mathrm{Cu}$ dissimilar interface.
\end{abstract}

Keywords: intermetallic compound; dissimilar metal joining; aluminum alloy; copper

\section{Introduction}

A multimaterial structure of dissimilar metals is required for performance improvement in commercial products. In particular, the combination of $\mathrm{Al}$ and $\mathrm{Cu}$ could reduce the weight and cost of electrical components [1,2]. The formation of an ideal structure in practical applications may require the dissimilar joining of $\mathrm{Al}$ alloy to $\mathrm{Cu}$. Mechanical joining [3] has potential as a solution for the dissimilar joining, but it generally results in an increase in weight of the products, which may be unaccepted in practical use. Therefore, metallurgical joining is often required as a suitable technique without an increase in weight of the products. However, a sound metallurgical joint is a great challenge to achieve because of the formation of an intermetallic compound (IMC) layer [4-6] at the $\mathrm{Al} / \mathrm{Cu}$ dissimilar interface through mutual diffusion during the joining process. The IMCs exhibit low ductility [5,7], resulting in a significant decrease in the interfacial strength of the $\mathrm{Al} / \mathrm{Cu}$ joint.

To achieve satisfactory dissimilar metal joints that exhibit good mechanical and electrical properties, reduction in the IMC layer thickness at the dissimilar interface is generally attempted because a thin IMC layer can alleviate the degradation of the joints [2,5,8-11]. Pan et al. [11] conducted heat treatment of $\mathrm{Al} / \mathrm{Cu}$ dissimilar friction welds and showed that a sufficient interfacial strength of the $\mathrm{Al} / \mathrm{Cu}$ dissimilar joint was obtained with an IMC layer thinner than $1 \mu \mathrm{m}$, which led to failure in the heat-affected zone. Xue et al. [10] examined the effect of heat treatment on $\mathrm{Al} / \mathrm{Cu}$ dissimilar friction stir welds and reported that the interfacial strength of dissimilar joints gradually decreased with the growth of a brittle IMC layer. Therefore, many attempts using low heat-input welding have been made to reduce the thickness of the IMC layer. For instance, the application of brazing 
between liquid $\mathrm{Al}$ and solid $\mathrm{Cu}$, such as arc brazing [12-15] and laser brazing [16-18], and solid-state joining, such as friction welding [19,20], friction stir welding [10,21-24], and ultrasonic spot welding [25-27], successfully suppressed the growth of the IMC layer, thereby improving the mechanical properties of the dissimilar joints.

The addition of alloying elements also has the potential to improve the mechanical properties of dissimilar joints. The microstructure of the IMC layer, such as the phase, grain size, thickness, and morphology, is strongly affected by alloying elements in the metals [28-33]. Xia et al. [28] showed that $\mathrm{Cu}_{15} \mathrm{Si}_{4}$ was formed at the interface between vacuum-brazed $\mathrm{Al}-\mathrm{Si}$ alloy and $\mathrm{Cu}$. Zhou et al. [32] reported that $\mathrm{Al}_{4.2} \mathrm{Cu}_{3.2} \mathrm{Zn}_{0.7}$ was formed in a laser weld between $\mathrm{Al}$ and brass. These studies show that the addition of alloying elements is an effective method for changing the joint properties at the dissimilar interface. However, the effect of alloying elements on joint properties associated with the microstructure of the IMC layer at the $\mathrm{Al} / \mathrm{Cu}$ dissimilar joint interface has not been systematically investigated.

Based on these findings, our research group attempted to examine the effect of alloying elements on the strength of the $\mathrm{Al} / \mathrm{Cu}$ dissimilar joint obtained via laser brazing [34]. This study showed that the addition of $\mathrm{Ni}$ to Al effectively improved the strength of the $\sim 5 \mu \mathrm{m}$ thick multi-IMC structured layer due to the formation of a $(\mathrm{Cu}, \mathrm{Ni}) \mathrm{Al}$ layer at the weak interface between the $\mathrm{Al}_{2} \mathrm{Cu}$ and $\mathrm{Al}_{4} \mathrm{Cu}_{9}$ layers. However, the fracture of $\mathrm{Al} / \mathrm{Cu}$ dissimilar joints generally occurs at various locations and is governed by the thickness of the multiIMC structured layer $[8,10,11,35,36]$. These results indicate that the effect of alloying elements on the strength of $\mathrm{Al} / \mathrm{Cu}$ dissimilar joints should depend on the joining method. However, the effect of $\mathrm{Ni}$ on the joint strength obtained with various joining methods has not yet been clarified.

In this study, $\mathrm{Al} / \mathrm{Cu}$ dissimilar lap joining with an $\mathrm{Al}-\mathrm{Ni}$ filler material was performed by tungsten inert gas (TIG) arc brazing that exhibited a relatively low cooling rate and a long reaction time. The effect of $\mathrm{Ni}$ on the interfacial strength at the $\mathrm{Al} / \mathrm{Cu}$ dissimilar joints was examined, and we attempted to clarify the microstructure of the IMC layers governing joint strength.

\section{Materials and Methods}

\subsection{Materials}

Oxygen-free $\mathrm{Cu} 1020$ and pure $\mathrm{Al} 1050$ were used as the base materials, and their chemical compositions are shown in Tables 1 and 2, respectively. The length, width, and thickness of the sheets were 100,50, and $2 \mathrm{~mm}$, respectively. To examine the effect of alloying elements on the joint strength and microstructure of the IMC layer, the Al-Ni filler material was prepared using a conventional casting method, and Al-X filler materials $(\mathrm{X}=\mathrm{Mn}, \mathrm{Si}, \mathrm{Cr}, \mathrm{Zn}$, or Sn) were also used for comparison. The content of each alloying element in $\mathrm{Al}$ was adjusted from 0 to 7 at.\%. The cast $\mathrm{Al}$ alloys were subjected to hot rolling to reduce solidification segregation and finished by cold rolling. The Al-X filler materials were finally prepared as bars with length, width, and thickness of 100,4 , and $2 \mathrm{~mm}$, respectively.

Table 1. Chemical composition of C1020 used in this study.

\begin{tabular}{ccc}
\hline Element & O & Cu \\
\hline wt. $\%$ & 0.0001 & 99.99 \\
\hline
\end{tabular}

Table 2. Chemical composition of A1050 used in this study.

\begin{tabular}{ccccccc}
\hline Element & $\mathbf{S i}$ & $\mathbf{F e}$ & $\mathbf{C u}$ & $\mathbf{T i}$ & $\mathbf{V}$ & $\mathbf{A l}$ \\
\hline wt. $\%$ & 0.10 & 0.24 & 0.01 & 0.01 & 0.02 & 99.59 \\
\hline
\end{tabular}




\subsection{Joining}

The $\mathrm{Al} / \mathrm{Cu}$ dissimilar lap joining with Al-X filler materials was performed via TIG arc brazing. A schematic of this process is presented in Figure 1. The surfaces of the joined materials were polished with 400-grit emery paper to remove the oxide layer, and thereafter covered by a flux (FT-170, TOYO METAL, Osaka, Japan) to improve the weldability of the dissimilar metals. The pure $\mathrm{Al}$ sheet was placed on the $\mathrm{Cu}$ sheet to achieve a lapped length of $20 \mathrm{~mm}$, and the $\mathrm{Al}-\mathrm{X}$ filler material was placed adjacent to the pure $\mathrm{Al}$ sheet, as shown in Figure 1. To increase the weldability, these materials were heated up to $200{ }^{\circ} \mathrm{C}$ with a hot plate under the $\mathrm{Cu}$ sheet during the joining process. The joining parameters were as follows: Joining current of $140 \mathrm{~A}$, arc voltage of $11 \mathrm{~V}$, arc length of $2 \mathrm{~mm}$, and joining speed of $200 \mathrm{~mm} / \mathrm{min}$. Ar shielding gas with a $20 \mathrm{~L} / \mathrm{min}$ flow rate was employed for arc brazing.

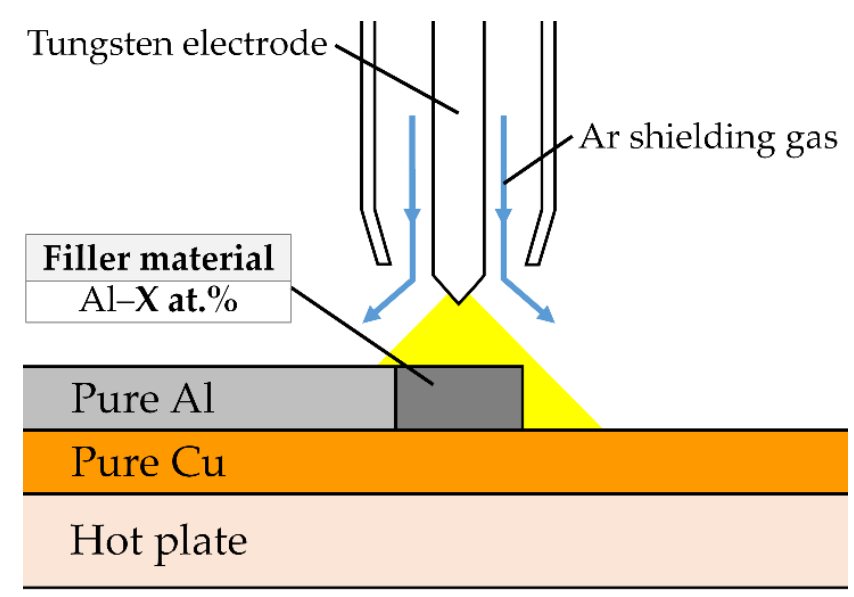

Figure 1. Schematic of dissimilar tungsten inert gas (TIG) arc brazing.

\subsection{Mechanical Testing}

The interfacial strength of the $\mathrm{Al} / \mathrm{Cu}$ dissimilar joints was evaluated by tensile shear strength testing. The configuration of the tensile specimen is presented in Figure 2. The specimens for this test were prepared as strips perpendicular to the joining direction. To fix the tested area in the tensile specimens at $20 \mathrm{~mm}^{2}$, two slits were cut into the $\mathrm{Al}$ fusion zone and $\mathrm{Cu}$ sheet using an electrical discharge machine, as shown in Figure $2 \mathrm{~b}$. The tensile shear strength testing was performed on a screw-driven testing machine at a crosshead speed of $0.3 \mathrm{~mm} / \mathrm{s}$ at room temperature. Spacers having the same thickness as the joined sheets were employed, as shown in Figure $2 \mathrm{a}$, for pure shearing during the tensile testing. The hardness and effective elastic modulus of the IMC formed at the dissimilar interface were examined by a nanoindentation system (Triboindenter, Hysitron Inc., Minneapolis, MN, USA). The measurement was performed using a Berkovich indenter (Triboindenter, Hysitron Inc., Minneapolis, MN, USA) under a 2000- $\mu \mathrm{N}$ load. The relationship between the reduced modulus and the elastic modulus of the materials is given by Equation (1) [37].

$$
\frac{1}{E}=\frac{1-v_{s}^{2}}{E_{s}}-\frac{1-v_{i}^{2}}{E_{i}}
$$

where $E$ is the reduced modulus; $v_{\mathrm{s}}$ and $E_{\mathrm{s}}$ are Poisson's ratio and elastic modulus of the specimen, respectively; and $v_{\mathrm{i}}$ and $E_{\mathrm{i}}$ are Poisson's ratio and elastic modulus of the indenter, respectively. The values of $v_{\mathrm{i}}$ and $E_{\mathrm{i}}$ of the Berkovich indenter in this study were 0.07 and $1140 \mathrm{GPa}$, respectively. The effective elastic modulus, $E^{*}$, which is used for comparison of the mechanical properties of the IMCs, is defined by Equation (2).

$$
E^{*}=\frac{E_{s}}{1-v_{s}^{2}}
$$


(a)

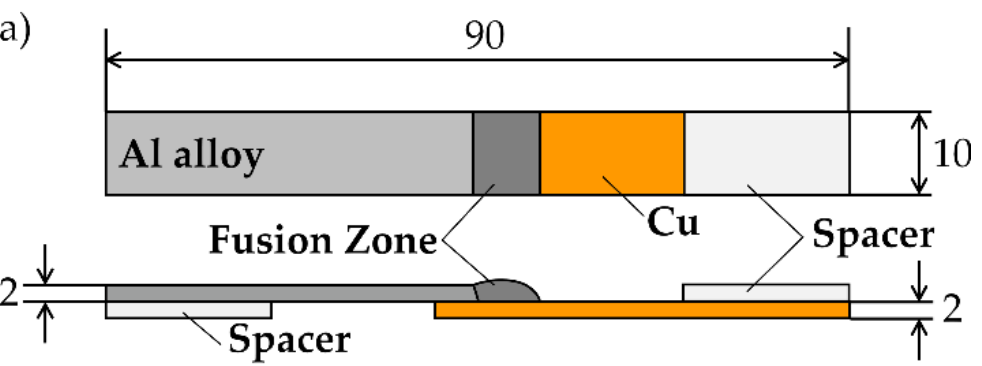

$(\mathrm{mm})$

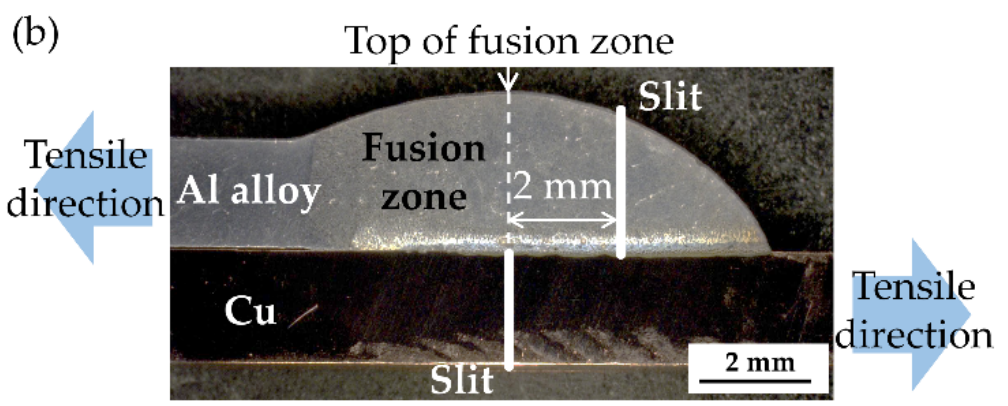

Figure 2. (a) Configuration and (b) location of the slits in the specimens used for tensile shear testing.

$E^{*}$ was calculated from Equation (2) using the reduced modulus and mechanical properties of the indenter.

\subsection{Microstructural Characterization}

After the tensile shear strength test, the fracture surfaces were examined via scanning electron microscopy (SEM) to determine the fracture mode at the $\mathrm{Al} / \mathrm{Cu}$ dissimilar joint interface. The chemical compositions of the fracture locations containing IMCs were examined using an electron probe microanalyzer (EPMA, JEOL, Akishima, Japan. The $\mathrm{Al} / \mathrm{Cu}$ dissimilar joint interface, including the reaction layer, was examined via optical microscopy (OM), SEM, EPMA, and the electron backscatter diffraction (EBSD) technique. The samples for EBSD analysis were prepared by vibratory polishing in a $50 \mathrm{~mL} \mathrm{H}_{2} \mathrm{O}+50 \mathrm{~mL}$ Struers OP-A solution for $10.8 \mathrm{ks}(3 \mathrm{~h})$.

\section{Results}

\subsection{Microstructural Characterization}

The relationship between the content of $\mathrm{Ni}$ in the $\mathrm{Al}$ filler material and the tensile shear strength is shown in Figure 3, and the effect of the other alloying elements is also presented for comparison. Regardless of the addition of alloying elements to the $\mathrm{Al}$ filler material, all tensile specimens fractured at the interface between the $\mathrm{Al}$ fusion zone and the $\mathrm{Cu}$ sheet. The tensile shear strength of the joint produced without alloying elements was approximately $35 \mathrm{MPa}$. The addition of $\mathrm{Ni}, \mathrm{Mn}, \mathrm{Si}, \mathrm{Cr}$, and $\mathrm{Zn}$ increased the interfacial strength of the $\mathrm{Al} / \mathrm{Cu}$ dissimilar joint at appropriate amounts of the alloying elements. Among the alloying elements that exhibited a positive effect, the addition of $\mathrm{Ni}$ at a concentration higher than 1 at.\% exhibited the most effective improvement in joint strength, which exceeded $45 \mathrm{MPa}$. On the contrary, the addition of $\mathrm{Sn}$ to the $\mathrm{Al}$ filler material tended to decrease joint strength, resulting in a strength reduction to $12 \mathrm{MPa}$ in the worst case. This study attempted to elucidate the reason for the increase in interfacial strength of the $\mathrm{Al} / \mathrm{Cu}$ dissimilar joint by the addition of $\mathrm{Ni}$. 


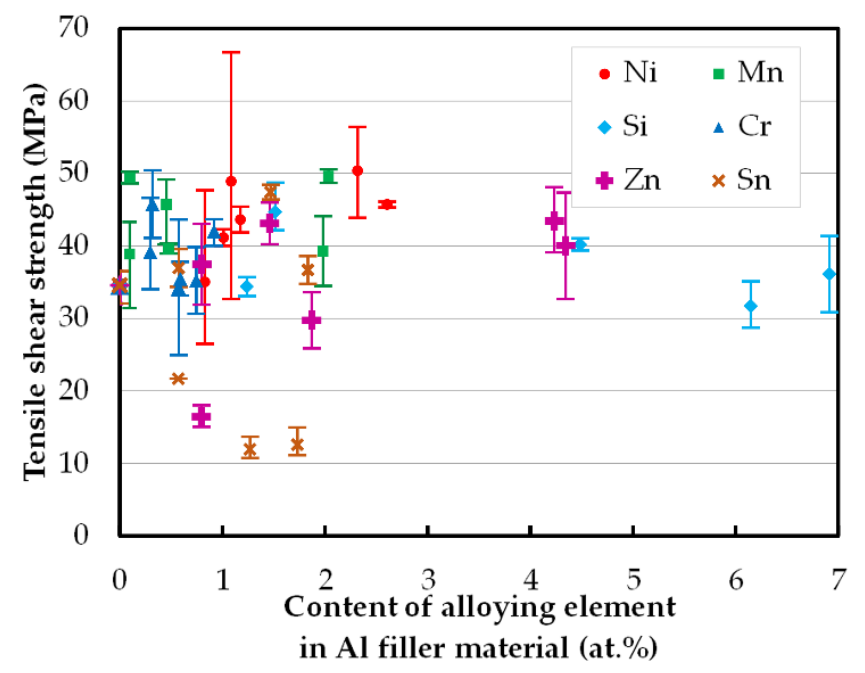

Figure 3. Effect of alloying elements in the Al filler material on the strength of the $\mathrm{Al} / \mathrm{Cu}$ dissimilar joints.

\subsection{Characteristics of the Reaction Layer}

The backscattered electron (BSE) images of the Al/Cu dissimilar joint interface without alloying elements are presented in Figure 4. The reaction layer formed at the dissimilar interface consisted of a eutectic structure in the Al fusion zone and an IMC layer adjacent to the $\mathrm{Cu}$, as shown in Figure $4 \mathrm{a}$. Based on the Al-Cu binary phase diagram, the eutectic structure was predicted as $\mathrm{Al}+\mathrm{Al}_{2} \mathrm{Cu}$ [38]. The high magnification images shown in Figure $4 b, c$ indicate that the IMC layer consisted of several IMC phases. The chemical compositions of the IMC phases produced without alloying elements are shown in Table 3 , and the analysis locations are indicated in Figure $4 \mathrm{c}$. Based on the results of the chemical composition analysis, the thick IMC layer below the eutectic structure was $\mathrm{Al}_{2} \mathrm{Cu}$, and the thin IMC layers near the $\mathrm{Cu}$, in order of appearance from the $\mathrm{Al}$ side, were $\mathrm{AlCu}, \mathrm{Al}_{3} \mathrm{Cu}_{4}$, and $\mathrm{Al}_{4} \mathrm{Cu}_{9}$. The chemical composition of the thinnest IMC layer adjacent to $\mathrm{Cu}$ could not be analyzed by EPMA in this study, but the Al-Cu binary phase diagram [38] implies that the thinnest layer was $\mathrm{AlCu}_{3}$ or $\mathrm{AlCu}_{4}$.
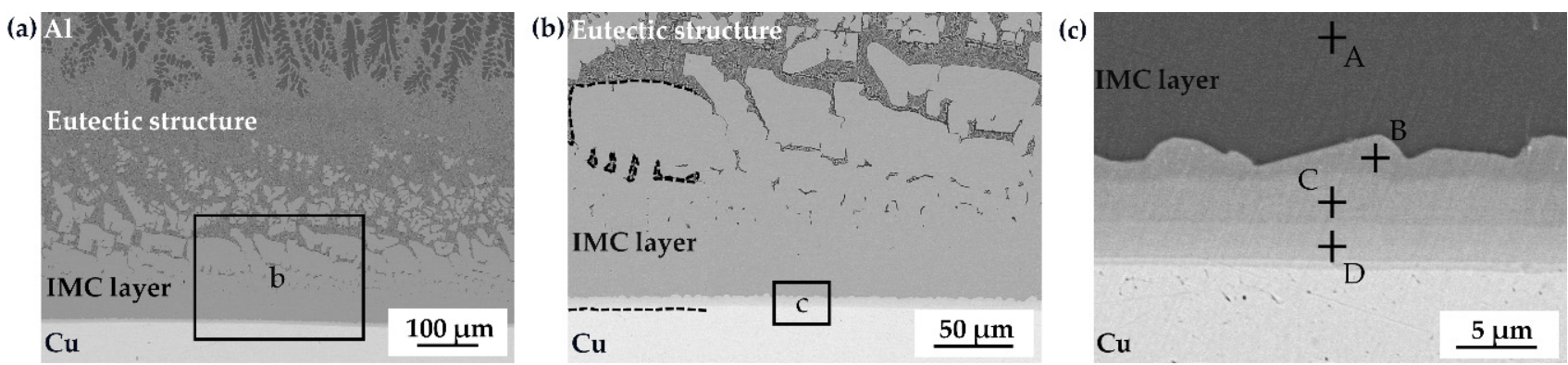

Figure 4. (a) Backscattered electron (BSE) image of the interfacial region with a reaction layer, (b,c) highly magnified BSE images of the intermetallic compound (IMC) layer located above the $\mathrm{Cu}$ in the $\mathrm{Al} / \mathrm{Cu}$ dissimilar joint without alloying elements.

Table 3. Chemical compositions of the IMC phases formed without alloying elements indicated in Figure 4 .

\begin{tabular}{|c|c|c|c|}
\hline \multirow{2}{*}{ Location } & \multicolumn{2}{|c|}{ Content (at.\%) } & \multirow{2}{*}{ Phase } \\
\hline & Al & $\mathrm{Cu}$ & \\
\hline A & 67.1 & 32.9 & $\mathrm{Al}_{2} \mathrm{Cu}$ \\
\hline $\mathrm{B}$ & 52.7 & 47.3 & $\mathrm{AlCu}$ \\
\hline $\mathrm{C}$ & 44.1 & 55.9 & $\mathrm{Al}_{3} \mathrm{Cu}_{4}$ \\
\hline $\mathrm{D}$ & 33.5 & 66.5 & $\mathrm{Al}_{4} \mathrm{Cu}_{9}$ \\
\hline
\end{tabular}


The BSE images of the $\mathrm{Al} / \mathrm{Cu}$ dissimilar joint interface produced with the addition of 2.3 at.\% Ni are presented in Figure 5, and the results of chemical composition analysis of IMC phases found in Figure $5 \mathrm{c}$ are shown in Table 4. Similar to the joint interface produced without alloying elements, the dissimilar interface had a typical reaction layer corresponding to the joining between liquid $\mathrm{Al}$ and solid $\mathrm{Cu}[4,5,12-18]$, i.e., a eutectic structure formed in the Al fusion zone and an IMC layer adjacent to the $\mathrm{Cu}$. The IMC layer mainly comprised a thick $\mathrm{Al}_{2} \mathrm{Cu}$ layer, as shown in Figure $5 \mathrm{~b}$ and Table 4 , as was found in the joint produced without alloying elements (Figure 4). Meanwhile, the addition of Ni produced particles in the $\mathrm{Al}_{2} \mathrm{Cu}$ layer with a higher $\mathrm{Ni}$ content than the other IMC phases, as shown in Figure $5 \mathrm{c}$. The phase map including the particles detected using the EBSD technique is given in Figure 6. $\mathrm{Al}_{7} \mathrm{Cu}_{4} \mathrm{Ni}$ particles (corresponding to the green region) were formed in $\mathrm{Al}_{2} \mathrm{Cu}$ (corresponding to the red region). Thin IMC layers were observed above the $\mathrm{Cu}$, as shown in Figure 5c. Two thin IMC layers were formed in the joint produced with the addition of Ni. The chemical composition analysis showed that the thin IMC layer adjacent to $\mathrm{Cu}$ was $\mathrm{Al}_{4} \mathrm{Cu}_{9}$, and the middle layer was $\mathrm{Al}_{3} \mathrm{Cu}_{4}$ or $(\mathrm{Ni}, \mathrm{Cu}) \mathrm{Al}$, as shown in Table 4 .
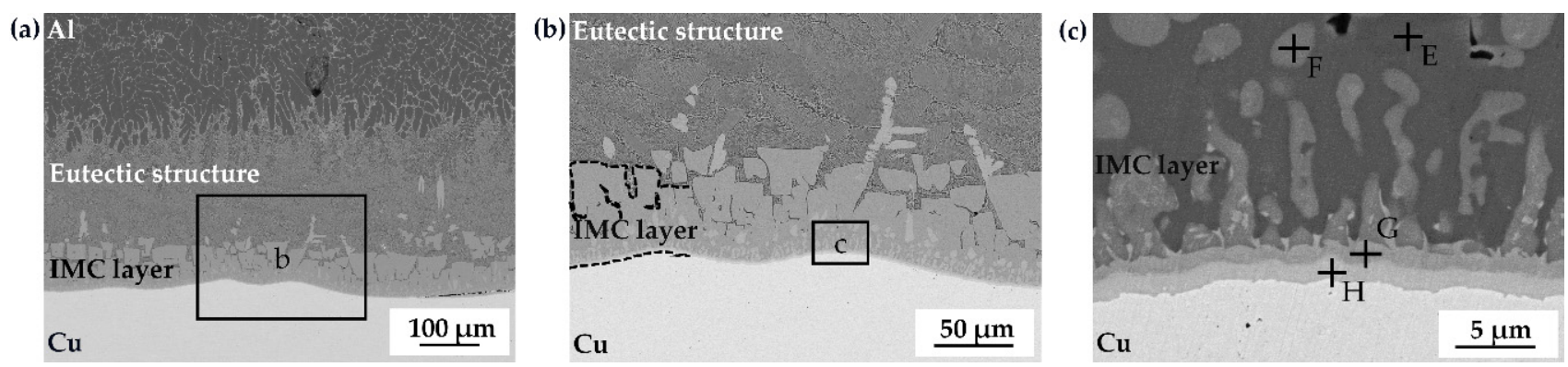

Figure 5. (a) BSE image of the interfacial region with a reaction layer, $(\mathbf{b}, \mathbf{c})$ highly magnified BSE image of an IMC layer located beside $\mathrm{Cu}$ in the $\mathrm{Al} / \mathrm{Cu}$ dissimilar joint with the addition of 2.3 at.\% $\mathrm{Ni}$ to the $\mathrm{Al}$ filler material.

Table 4. Chemical compositions of the IMC phases formed with 2.3 at.\% Ni indicated in Figure 5.

\begin{tabular}{ccccc}
\hline \multirow{2}{*}{ Location } & \multicolumn{3}{c}{ Content (at.\%) } & Phase \\
\cline { 2 - 4 } & $\mathbf{A l}$ & $\mathbf{C u}$ & $\mathbf{N i}$ & $\mathrm{Al}_{2} \mathrm{Cu}$ \\
$\mathrm{E}$ & 65.2 & 33.7 & 1.1 & - \\
$\mathrm{F}$ & 62.0 & 35.1 & 2.9 & $\mathrm{Al}_{3} \mathrm{Cu}_{4}$ or $(\mathrm{Cu}, \mathrm{Ni}) \mathrm{Al}$ \\
$\mathrm{G}$ & 44.6 & 54.7 & 0.6 & $\mathrm{Al}_{4} \mathrm{Cu}$ \\
$\mathrm{H}$ & 33.6 & 66.1 & 0.3 & \\
\hline
\end{tabular}

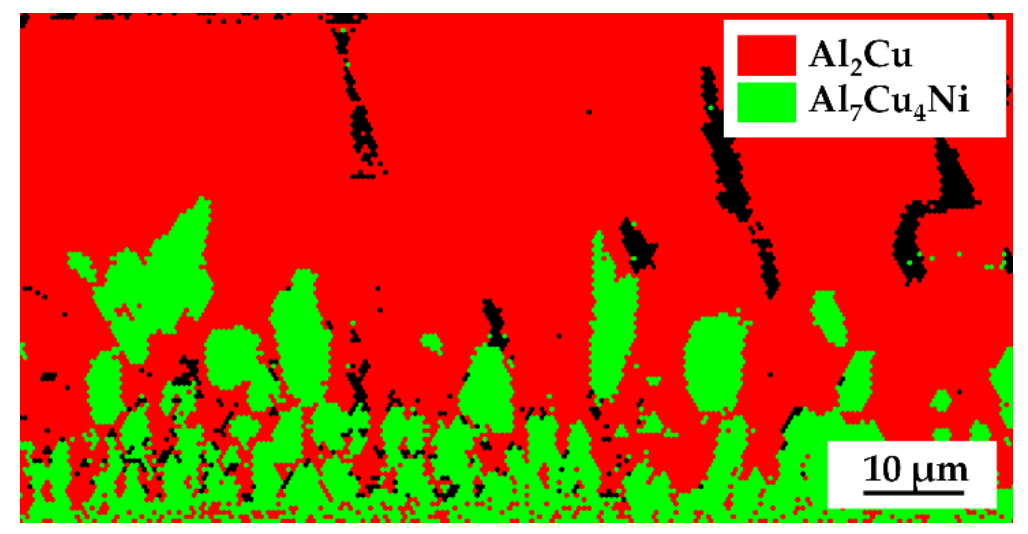

Figure 6. Electron backscatter diffraction (EBSD) phase map at the $\mathrm{Al}_{2} \mathrm{Cu}$ layer with $\mathrm{Ni}$-containing particles formed at the joint by the addition of 2.3 at. $\% \mathrm{Ni}$. 


\subsection{Fracture Location within the Dissimilar Joint}

The BSE images of the fracture surfaces of the tensile specimens produced without alloying elements and with 2.3 at.\% $\mathrm{Ni}$ are presented in Figure 7 . The results of a chemical composition analysis of the fracture surfaces are listed in Table 5, and the identified phases, which were comprehensively judged using the chemical compositions and the microstructures on the cross-sections analyzed by EBSD, were also presented. Regardless of the $\mathrm{Ni}$ addition, all the fractured specimens exhibited a flat surface without any dimple patterns, indicating a brittle fracture. In the joints without alloying elements, BSE images of both the $\mathrm{Al}$ - and $\mathrm{Cu}$-side fractured surfaces displayed negligible contrast differences arising from the chemical composition, which the chemical composition analysis revealed to be $\mathrm{Al}_{2} \mathrm{Cu}$. These results showed that during the tensile shear test, the brittle fracture occurred in the $\mathrm{Al}_{2} \mathrm{Cu}$ layer formed at the $\mathrm{Al} / \mathrm{Cu}$ dissimilar joint interface. However, additional particles containing $\mathrm{Ni}$, i.e., $\mathrm{Al}_{7} \mathrm{Cu}_{4} \mathrm{Ni}$ particles, were observed on the fracture surfaces of the joint produced with the Al-Ni filler material. Based on the cross-sectional observation (Figure 5) and the chemical composition analysis (Table 4), it was suggested that the joint failed in the $\mathrm{Al}_{2} \mathrm{Cu}$ layer with $\mathrm{Al}_{7} \mathrm{Cu}_{4} \mathrm{Ni}$ particles.
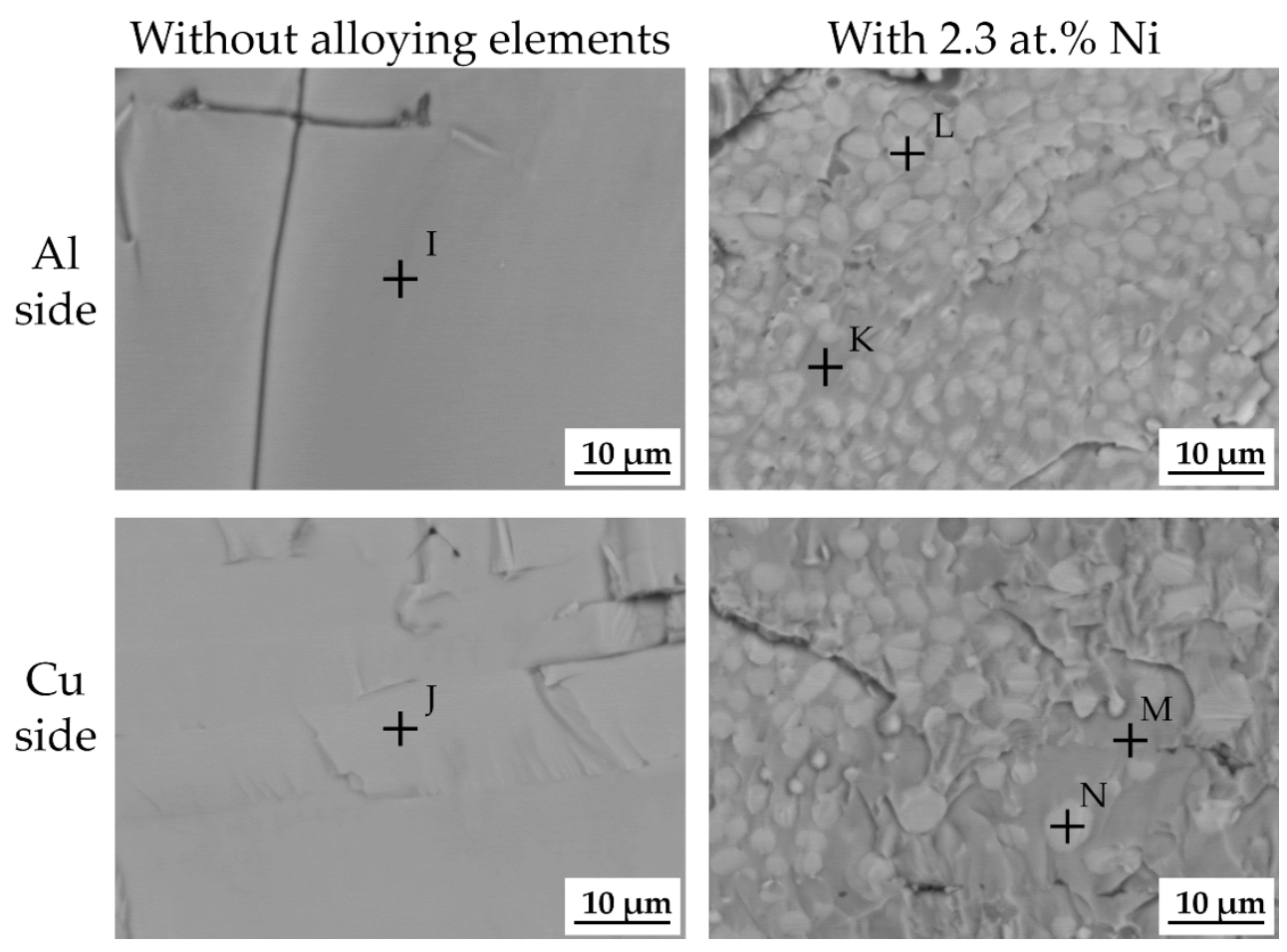

Figure 7. BSE images of the fracture surfaces of the $\mathrm{Al} / \mathrm{Cu}$ dissimilar joints without alloying elements and with the addition of 2.3 at. $\% \mathrm{Ni}$.

Table 5. Chemical compositions of the fracture surfaces indicated in Figure 7.

\begin{tabular}{ccccc}
\hline \multirow{2}{*}{ Location } & \multicolumn{3}{c}{ Content (at.\%) } & \multirow{2}{*}{ Phase } \\
\cline { 2 - 4 } & $\mathbf{A l}$ & $\mathbf{C u}$ & $\mathbf{N i}$ & \\
\hline $\mathrm{I}$ & 68.9 & 31.1 & - & $\mathrm{Al}_{2} \mathrm{Cu}$ \\
J & 69.4 & 30.6 & - & $\mathrm{Al}_{2} \mathrm{Cu}$ \\
K & 69.8 & 29.9 & 0.3 & $\mathrm{Al}_{2} \mathrm{Cu}$ \\
L & 60.2 & 36.2 & 3.6 & $\mathrm{Al}_{7} \mathrm{Cu}_{4} \mathrm{Ni}$ \\
M & 67.7 & 31.9 & 0.4 & $\mathrm{Al}_{2} \mathrm{Cu}$ \\
N & 55.3 & 41.6 & 3.1 & $\mathrm{Al}_{7} \mathrm{Cu}_{4} \mathrm{Ni}$ \\
\hline
\end{tabular}

\subsection{Hardness of Fractured IMCs}

The hardness and effective elastic modulus of the fractured IMCs, i.e., $\mathrm{Al}_{2} \mathrm{Cu}$ and $\mathrm{Al}_{7} \mathrm{Cu}_{4} \mathrm{Ni}$, obtained by nanoindentation measurements, are shown in Figure 8 . The $\mathrm{Al}_{2} \mathrm{Cu}$ 
at the dissimilar joint produced without alloying elements exhibited hardness of $8.8 \mathrm{GPa}$ and elastic modulus of $142 \mathrm{GPa}$. These mechanical properties of $\mathrm{Al}_{2} \mathrm{Cu}$ were hardly affected by the addition of Ni. Meanwhile, the hardness and elastic modulus of $\mathrm{Al}_{7} \mathrm{Cu}_{4} \mathrm{Ni}$ were 10.8 GPa and $198 \mathrm{GPa}$, respectively, which were higher than those of $\mathrm{Al}_{2} \mathrm{Cu}$. Based on the identification of the fracture location (Figure 7 and Table 5), this result indicates that hard and highly elastic $\mathrm{Al}_{7} \mathrm{Cu}_{4} \mathrm{Ni}$ particles were present on the fracture path during the strength testing.

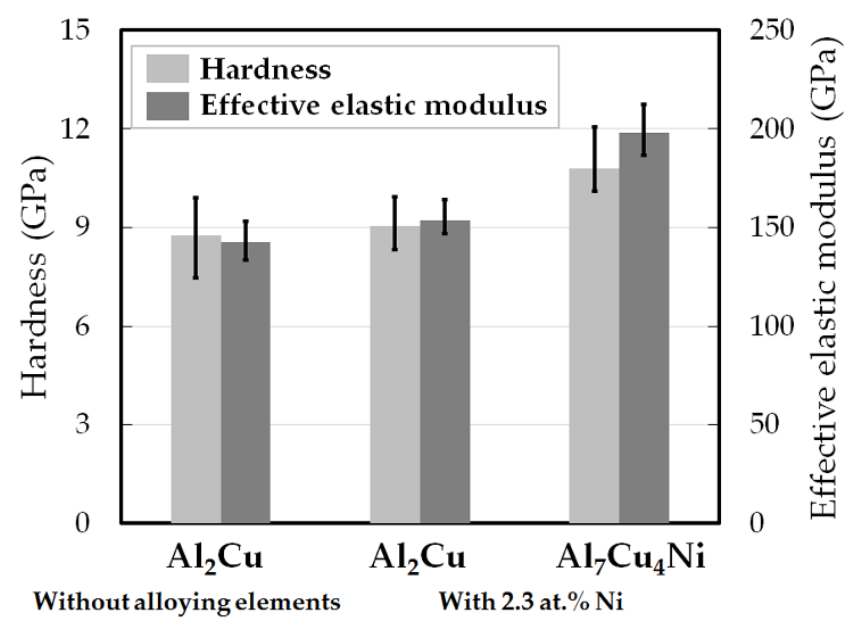

Figure 8. Hardness and effective elastic modulus of fractured IMCs in the Al/Cu dissimilar joints.

\section{Discussion}

\subsection{Formation of the Reaction Layer}

During the reaction between liquid $\mathrm{Al}$ and solid $\mathrm{Cu}$, a reaction layer consisting of an $\mathrm{Al}+\mathrm{Al}_{2} \mathrm{Cu}$ eutectic structure and a thick $\mathrm{Al}_{2} \mathrm{Cu}$ layer was typically formed at the dissimilar interface $[4,5,12-18]$. Rapid dissolution of $\mathrm{Cu}$ into liquid $\mathrm{Al}$ resulted in a hypereutectic composition, leading to the formation of an $\mathrm{Al}_{2} \mathrm{Cu}$ layer followed by a eutectic structure during the solidification process $[4,5]$. Further reaction results in the formation of several thin IMC phases, such as $\mathrm{AlCu}, \mathrm{Al}_{3} \mathrm{Cu}_{4}, \mathrm{Al}_{2} \mathrm{Cu}_{3}$, and $\mathrm{Al}_{4} \mathrm{Cu}_{9}$ [5], by interdiffusion between $\mathrm{Al}_{2} \mathrm{Cu}$ and solid $\mathrm{Cu}$. In this study, the relatively large heat input by TIG arc brazing and the accompanying heating using a hot plate should result in a high joining temperature for a long reaction time, which causes the formation of a thick $\mathrm{Al}_{2} \mathrm{Cu}$ layer with several IMCs at the $\mathrm{Al} / \mathrm{Cu}$ dissimilar joint interface, as shown in Figure 4.

According to the Al-Cu-Ni ternary phase diagram [39], it is expected that the addition of $\mathrm{Ni}$ resulted in the formation of $\mathrm{Al}_{7} \mathrm{Cu}_{4} \mathrm{Ni}$ and $(\mathrm{Ni}, \mathrm{Cu}) \mathrm{Al} .(\mathrm{Ni}, \mathrm{Cu}) \mathrm{Al}$ is generally a stable phase having large negative free energy over a wide range of chemical compositions and temperatures. Furuya et al. [34] reported that a $(\mathrm{Ni}, \mathrm{Cu}) \mathrm{Al}$ layer was observed between the $\mathrm{Al}_{2} \mathrm{Cu}$ and $\mathrm{Al}_{4} \mathrm{Cu}_{9}$ layers at the dissimilar interface during laser brazing (which has lower heat input than TIG arc brazing) between Al-Ni alloy and pure $\mathrm{Cu}$. These results suggest that a $(\mathrm{Ni}, \mathrm{Cu}) \mathrm{Al}$ layer is inevitably formed by the addition of $\mathrm{Ni}$ at the $\mathrm{Al} / \mathrm{Cu}$ dissimilar interface, implying that the IMC phase of location $\mathrm{G}$ in Figure $5 \mathrm{c}$ was $(\mathrm{Ni}, \mathrm{Cu}) \mathrm{Al}$. This would explain why the addition of $\mathrm{Ni}$ to the $\mathrm{Al}$ filler material promotes the formation of $\mathrm{Al}_{7} \mathrm{Cu}_{4} \mathrm{Ni}$ particles and a $(\mathrm{Ni}, \mathrm{Cu}) \mathrm{Al}$ layer, instead of several Al-Cu binary IMCs, as shown in Figure 5c.

\subsection{Thickness of the IMC Layer}

The thickness of the IMC layer at the dissimilar joint interface was reduced by the addition of $\mathrm{Ni}$, as shown in Figures $4 \mathrm{~b}$ and $5 \mathrm{~b}$. A decrease in the thickness of the IMC layer formed at a dissimilar interface increases joint strength [2,5,8-11]. Xue et al. [10] conducted heat treatment of $\mathrm{Al} / \mathrm{Cu}$ friction stir welds and demonstrated that thick IMC layers exhibited low strengths at a dissimilar joint interface. Lee et al. [9] also reported that the growth of an IMC layer decreased the joint strength of $\mathrm{Al} / \mathrm{Cu}$ dissimilar friction 
stir welds. The thickness reduction of the IMC layer by the addition of $\mathrm{Ni}$ might be a microstructural factor that improves the interfacial strength of the $\mathrm{Al} / \mathrm{Cu}$ dissimilar joint.

\subsection{Dispersion of the IMC Particles}

Several studies have reported crack propagation in the $\mathrm{Al}_{2} \mathrm{Cu}$ layer formed at the $\mathrm{Al} / \mathrm{Cu}$ dissimilar joint [11-13]. Pan et al. [11] examined the fracture location of the $\mathrm{Al} / \mathrm{Cu}$ dissimilar joint with various IMC thicknesses and reported that a fracture of the $\mathrm{Al} / \mathrm{Cu}$ dissimilar joint propagated in $\mathrm{Al}_{2} \mathrm{Cu}$ when a relatively thick IMC layer formed at the interface. Feng et al. [12] reported that the $\mathrm{Al} / \mathrm{Cu}$ dissimilar joint produced by metal inert gas arc brazing using cold metal transfer technology mainly failed in a thick $\mathrm{Al}_{2} \mathrm{Cu}$ layer, even though several IMCs were observed at the dissimilar interface. These studies imply that the failure in the $\mathrm{Al}_{2} \mathrm{Cu}$ layer can be dominant in the $\mathrm{Al} / \mathrm{Cu}$ dissimilar joint with a thick IMC layer, which is consistent with the result of this study, as shown in Figure 7.

The strength improvement of brittle materials by reinforcing particles is caused by the mechanisms of crack bowing, crack deflection, and crack bridging [40-43]. Serbena et al. [41] conducted heat treatment of photo-thermo-refractive glass and showed that crack deflection was caused by residual stress arising from the elastic mismatch between the matrix and fine $\mathrm{NaF}$ particles, increasing the fracture strength and toughness. They [42] also reported that ceramic particles of $\mathrm{Li}_{2} \mathrm{Si}_{2} \mathrm{O}_{5}$ effectively increase the flexural strength of lithium disilicate glass and concluded that crack bowing is the main strengthening mechanism responsible for the higher elastic modulus and toughness of the particles. Khan [43] et al. examined the mechanical properties of $\mathrm{Ca}-\alpha-\mathrm{SiAlON}$ with a dispersion of hard $\mathrm{SiC}$ particles and showed that crack deflection and crack bridging improved the toughness of the material. In this study, the effective and dominant mechanisms of strengthening by particles are unclear, but there is a high possibility that the hard and highly elastic $\mathrm{Al}_{7} \mathrm{Cu}_{4} \mathrm{Ni}$ particles acted as reinforcing particles in the brittle $\mathrm{Al}_{2} \mathrm{Cu}$ layer.

\subsection{Strength Improvement Mechanism with Addition of $\mathrm{Ni}$}

The effect of the addition of $\mathrm{Ni}$ on the microstructure of the IMC layer at the $\mathrm{Al} / \mathrm{Cu}$ dissimilar joint interface is summarized in Figure 9. The IMC layer at the dissimilar interface produced without alloying elements comprised a thick $\mathrm{Al}_{2} \mathrm{Cu}$ layer and several thin IMC layers in order from the $\mathrm{Al}$ side to the $\mathrm{Cu}$ side, as shown in Figure 4 and Table 3. The dissimilar joint failed in the $\mathrm{Al}_{2} \mathrm{Cu}$ layer during strength testing, as presented in Figure 7 and Table 5. The IMC layer produced with $\mathrm{Ni}$ also consisted of a thick $\mathrm{Al}_{2} \mathrm{Cu}$ layer and thin IMC layers, but the thick $\mathrm{Al}_{2} \mathrm{Cu}$ layer included $\mathrm{Al}_{7} \mathrm{Cu}_{4} \mathrm{Ni}$ particles (Figure 5). The thickness of the IMC layer was clearly reduced by the addition of $\mathrm{Ni}$ into the $\mathrm{Al}$ filler material. The fracture of the dissimilar joint also occurred in the $\mathrm{Al}_{2} \mathrm{Cu}$ layer, but the hard and highly elastic $\mathrm{Al}_{7} \mathrm{Cu}_{4} \mathrm{Ni}$ particles were present on the fracture path that acted as reinforcing particles in the brittle $\mathrm{Al}_{2} \mathrm{Cu}$ layer, as shown in Figure 7. The thickness reduction and dispersion strengthening caused by the addition of $\mathrm{Ni}$ could be a reason for the apparent improvement in the strength of the $\mathrm{Al} / \mathrm{Cu}$ dissimilar joint by the addition of $\mathrm{Ni}$.

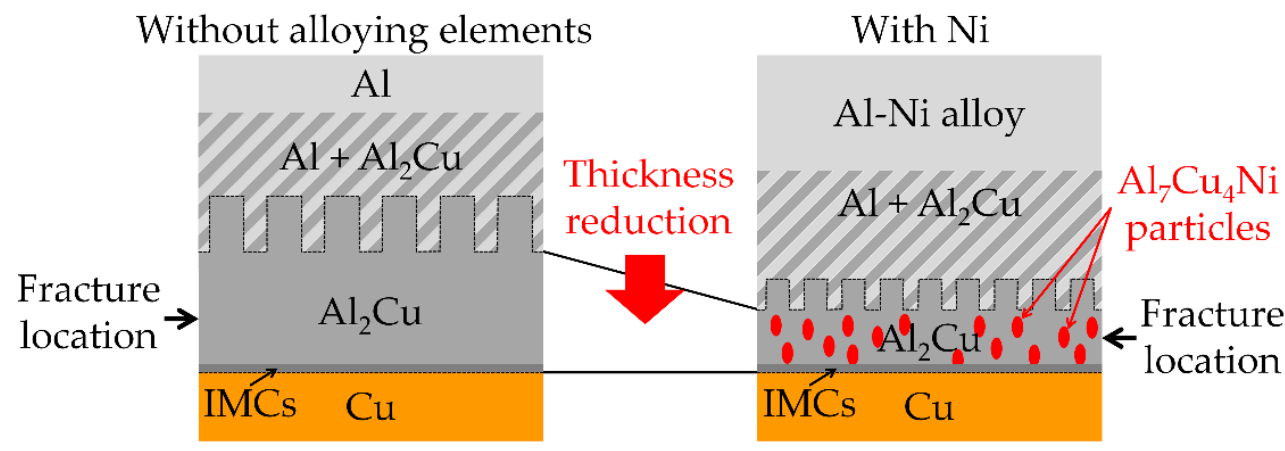

Figure 9. Schematic of the $\mathrm{Al} / \mathrm{Cu}$ dissimilar interface and fracture location of the joint produced without alloying elements, and with the addition of $\mathrm{Ni}$ to $\mathrm{Al}$. 
Our research group previously showed that the strength of the $\mathrm{Al} / \mathrm{Cu}$ dissimilar joint obtained via laser brazing was improved by the addition of $\mathrm{Ni}$, resulting from the formation of a $(\mathrm{Cu}, \mathrm{Ni}) \mathrm{Al}$ layer at the weak interface between the $\mathrm{Al}_{2} \mathrm{Cu}$ and $\mathrm{Al}_{4} \mathrm{Cu}_{9}$ layers [34], which is a different mechanism obtained in this study. The definitive difference in the $\mathrm{Al} / \mathrm{Cu}$ dissimilar joints produced by arc and laser brazing is the fracture location within the IMC layers formed at the joint interface. The fracture location of the $\mathrm{Al} / \mathrm{Cu}$ dissimilar joints is generally governed by the thickness of the IMC layer [8,10,11,35,36]. Wallach et al. [35] reported that the failure mechanism of the $\mathrm{Al} / \mathrm{Cu}$ joint transformed from intergranular between different IMC layers into transgranular in IMC when the thickness of IMC layer is greater than $25 \mu \mathrm{m}$. Pan et al. [11] also reported that, in the case of a thin IMC layer, the fracture occurred at the interface between the $\mathrm{Al}_{2} \mathrm{Cu}$ and $\mathrm{Al}_{4} \mathrm{Cu}_{9}$ layers, while in the case of a thick IMC layer, the crack propagated inside the $\mathrm{Al}_{2} \mathrm{Cu}$ layer. In our research, the $\mathrm{Al}_{2} \mathrm{Cu}$ layer with over $30 \mu \mathrm{m}$ thickness (produced via TIG arc brazing) tended to fail in the $\mathrm{Al}_{2} \mathrm{Cu}$ layer, whereas an IMC layer thinner than about $5 \mu \mathrm{m}$ (produced via laser brazing) mostly failed at the interface between IMC layers [34]. The difference in fracture location observed between the arc- and laser-brazed $\mathrm{Al} / \mathrm{Cu}$ dissimilar joints indicates a different mechanism for strength improvement. However, the reason why the fracture location within the IMC layer depends on the thickness remains unclear.

\section{Conclusions}

The effect of the addition of $\mathrm{Ni}$ to the $\mathrm{Al}$ filler material on the strength associated with the microstructure of the IMC layer at the $\mathrm{Al} / \mathrm{Cu}$ dissimilar joint interface was examined. The addition of Ni effectively increased the interfacial strength of the dissimilar joint. The IMC layer at the dissimilar joint interface was composed mainly of a thick $\mathrm{Al}_{2} \mathrm{Cu}$ layer, resulting in brittle fracture of the joint, regardless of the addition of $\mathrm{Ni}$ to Al. However, the addition of $\mathrm{Ni}$ reduced the thickness of the $\mathrm{Al}_{2} \mathrm{Cu}$ layer at the dissimilar interface and yielded the formation of $\mathrm{Al}_{7} \mathrm{Cu}_{4} \mathrm{Ni}$ particles in the fractured $\mathrm{Al}_{2} \mathrm{Cu}$ layer. This study showed that the thickness reduction and reinforcing particles formation by the addition of $\mathrm{Ni}$ to $\mathrm{Al}$ increased the interfacial strength of the $\mathrm{Al} / \mathrm{Cu}$ dissimilar joint.

Author Contributions: Conceptualization, Y.S.S. methodology, H.S.F. and Y.S.S.; formal analysis, H.S.F. and S.Y.; investigation, S.Y.; resources, Y.S.S. and H.K.; data curation, H.S.F. and S.Y.; writingoriginal draft preparation, H.S.F.; writing — review and editing, Y.S.S. and H.K.; visualization, H.S.F.; supervision, Y.S.S. and H.K.; project administration, Y.S.S.; funding acquisition, Y.S.S. All authors have read and agreed to the published version of the manuscript.

Funding: This research was partly funded by the Program for Leading Graduate Schools "Interdepartmental Doctoral Degree Program for Multi-dimensional Materials Science Leaders" by the Ministry of Education, Culture, Sports, Science and Technology in Japan.

Data Availability Statement: Not applicable.

Acknowledgments: The authors are grateful to A. Honda and K. Kobayashi for their technical assistance and acknowledge N. Hirata for the preparation of the Al alloy used in this study. They also wish to thank T. Narushima and R. Kainuma for their helpful discussion.

Conflicts of Interest: The authors declare no conflict of interest.

\section{References}

1. Immarigeon, J.P.; Holt, R.P.; Koul, A.K.; Zhao, L.; Wallace, W.; Beddoes, J.C. Lightweight materials for aircraft applications. Mater. Charact. 1995, 35, 41-67. [CrossRef]

2. Uscinowicz, R. Impact of temperature on shear strength of single lap Al-Cu bimetallic joint. Compos. Part B 2013, 44, 344-356. [CrossRef]

3. Urbikain, G.; Perez, J.M.; de Lacalle, L.N.L.; Andueza, A. Combination of friction drilling and form tapping processes on dissimilar materials for making nutless joints. Proc. IMechE Part B J. Eng. Manuf. 2018, 232, 1007-1020. [CrossRef]

4. Wang, T.M.; Cao, F.; Zhou, P.; Kang, H.J.; Chen, Z.N.; Fu, Y.N.; Xiao, T.Q.; Huang, W.X.; Yuan, Q.X. Study on diffusion behavior and microstructural evolution of $\mathrm{Al} / \mathrm{Cu}$ bimetal interface by synchrotron X-ray radiography. J. Alloys Compd. 2014, 616, 550-555. [CrossRef] 
5. Tavassoli, S.; Abbasi, M.; Tahavvori, R. Controlling of IMCs layers formation sequence, bond strength and electrical resistance in Al-Cu bimetal compound casting process. Mater. Des. 2016, 108, 343-353. [CrossRef]

6. Chen, C.Y.; Hwang, W.S. Effect of Annealing on the Interfacial Structure of Aluminum-Copper Joints. Mater. Trans. 2007, 48, 1938-1947. [CrossRef]

7. Gueydan, A.; Domengès, B.; Hug, E. Study of the intermetallic growth in copper-clad aluminum wires after thermal aging. Intermetallics 2014, 50, 34-42. [CrossRef]

8. Abbasi, M.; Karimi Taheri, A.; Salehi, M.T. Growth rate of intermetallic compounds in Al/Cu bimetal produced by cold roll welding process. J. Alloys Compd. 2001, 319, 233-241. [CrossRef]

9. Lee, W.B.; Bang, K.S.; Jung, S.B. Effects of intermetallic compound on the electrical and mechanical properties of friction welded $\mathrm{Cu} / \mathrm{Al}$ bimetallic joints during annealing. J. Alloys Compd. 2005, 390, 212-219. [CrossRef]

10. Xue, P.; Xiao, B.L.; Ma, Z.Y. Effect of Interfacial Microstructure Evolution on Mechanical Properties and Fracture Behavior of Friction Stir-Welded Al-Cu Joints. Metall. Mater. Trans. A 2015, 46, 3091-3103. [CrossRef]

11. Pan, L.; Li, P.; Hao, X.; Zhou, J.; Dong, H. Inhomogeneity of microstructure and mechanical properties in radial direction of aluminum/copper friction welded joints. J. Mater. Process. Technol. 2018, 255, 308-318. [CrossRef]

12. Feng, J.C.; Liu, Y.B.; Sun, Q.J.; Liu, J.P.; Wu, L.J. Microstructures and Properties of Aluminum-Copper Lap-Welded Joints by Cold Metal Transfer Technology. Adv. Eng. Mater. 2015, 17, 1480-1485. [CrossRef]

13. Cai, Z.P.; Ai, B.Q.; Cao, R.; Lin, Q.; Chen, J.H. Microstructure and properties of aluminum AA6061-T6 to copper (Cu)-T2 joints by cold metal transfer joining technology. J. Mater. Res. 2016, 31, 2876-2887. [CrossRef]

14. Zhou, X.L.; Zhang, G.; Shi, Y.; Zhu, M.; Yang, F.Q. Microstructures and mechanical behavior of aluminum-copper lap joints. Mater. Sci. Eng. A 2017, 705, 105-113. [CrossRef]

15. Wojdat, T.; Kustron, P.; Margielewska, A.; Stachowicz, M. Microstructure and Mechanical Properties of Braze Welded Joints of Copper with Austenitic Steel Made by CMT Method. Arch. Metall. Mater. 2019, 64, 1411-1420.

16. Mai, T.A.; Spowage, A.C. Characterisation of dissimilar joints in laser welding of steel-kovar, copper-steel and copper-aluminium. Mater. Sci. Eng. A 2004, 374, 224-233. [CrossRef]

17. Solchenbach, T.; Plapper, P. Mechanical characteristics of laser braze-welded aluminium-copper connections. Opt. Laser Technol. 2013, 54, 249-256. [CrossRef]

18. Schmalen, P.; Plapper, P. Evaluation of Laser Braze-welded Dissimilar Al-Cu Joints. Phys. Procedia 2016, 83, 506-514. [CrossRef]

19. Wei, Y.N.; Li, J.L.; Xiong, J.T.; Zhang, F.S. Investigation of interdiffusion and intermetallic compounds in Al-Cu joint produced by continuous drive friction welding. J. Eng. Sci. Technol. 2016, 19, 90-95. [CrossRef]

20. Li, W.Y.; Wen, Q.; Yang, X.W.; Wang, Y.S.; Gao, D.L.; Wang, W.B. Interface microstructure evolution and mechanical properties of $\mathrm{Al} / \mathrm{Cu}$ bimetallic tubes fabricated by a novel friction-based welding technology. Mater. Des. 2017, 134, 383-393. [CrossRef]

21. Xue, P.; Xiao, B.L.; Ni, D.R.; Ma, Z.Y. Enhanced mechanical properties of friction stir welded dissimilar Al-Cu joint by intermetallic compounds. Mater. Sci. Eng. A 2010, 527, 5723-5727. [CrossRef]

22. Muthu, M.F.X.; Jayabalan, V. Tool travel speed effects on the microstructure of friction stir welded aluminum-copper joints. J. Mater. Process. Technol. 2015, 217, 105-113. [CrossRef]

23. Mehta, K.P.; Badheka, V.J. Hybrid approaches of assisted heating and cooling for friction stir welding of copper to aluminum joints. J. Mater. Process. Technol. 2017, 239, 336-345. [CrossRef]

24. Osman, N.; Sajuri, Z.; Baghdadi, A.H.; Omar, M.Z. Effect of Process Parameters on Interfacial Bonding Properties of AluminiumCopper Clad Sheet Processed by Multi-Pass Friction Stir-Welding Technique. Metals 2019, 9, 1159. [CrossRef]

25. Matsuoka, S.I.; Imai, H. Direct welding of different metals used ultrasonic vibration. J. Mater. Process. Technol. 2009, 209, 954-960. [CrossRef]

26. Zhao, Y.Y.; Li, D.; Zhang, Y.S. Effect of welding energy on interface zone of Al-Cu ultrasonic welded joint. Sci. Technol. Weld. Join. 2013, 18, 354-360. [CrossRef]

27. Yang, J.W.; Cao, B.; He, X.C.; Luo, H.S. Microstructure evolution and mechanical properties of Cu-Al joints by ultrasonic welding. Sci. Technol. Weld. Join. 2014, 19, 500-504. [CrossRef]

28. Xia, C.Z.; Li, Y.J.; Puchkov, U.A.; Gerasimov, S.A.; Wang, J. Microstructure and phase constitution near the interface of Cu/Al vacuum brazing using Al-Si filler metal. Vacuum 2008, 82, 799-804. [CrossRef]

29. Esmaeili, A.; Zareie Rajani, H.R.; Sharbati, M.; Besharati Givi, M.K.; Shamanian, M. The role of rotation speed on intermetallic compounds formation and mechanical behavior of friction stir welded brass/aluminum 1050 couple. Intermetallics 2011, 19, 1711-1719. [CrossRef]

30. Springer, H.; Kostka, A.; Payton, E.J.; Raabe, D.; Kaysser-Pyzalla, A.; Eggeler, G. On the formation and growth of intermetallic phases during interdiffusion between low-carbon steel and aluminum alloys. Acta Mater. 2011, 59, 1586-1600. [CrossRef]

31. Feng, J.; Songbai, X.; Wai, D. Reliability studies of $\mathrm{Cu} / \mathrm{Al}$ joints brazed with Zn-Al-Ce filler metals. Mater. Des. 2012, 42, 156-163. [CrossRef]

32. Zhou, L.; Luo, L.Y.; Tan, C.W.; Li, Z.Y.; Song, X.G.; Zhao, H.Y.; Huang, Y.X.; Feng, J.C. Effect of welding speed on microstructural evolution and mechanical properties of laser welded-brazed Al/brass dissimilar joints. Opt. Laser Technol. 2018, 98, 234-246. [CrossRef] 
33. Furuya, H.S.; Sato, Y.T.; Sato, Y.S.; Kokawa, H.; Tatsumi, Y. Strength Improvement Through Grain Refinement of Intermetallic Compound at Al/Fe Dissimilar Joint Interface by the Addition of Alloying Elements. Metall. Mater. Trans. A 2018, 49, 527-536. [CrossRef]

34. Furuya, H.S.; Sato, Y.S.; Kokawa, H.; Huang, T.; Xiao, R.S. Improvement of Interfacial Strength with the Addition of $\mathrm{Ni}$ in $\mathrm{Al} / \mathrm{Cu}$ Dissimilar Joints Produced via Laser Brazing. Metall. Mater. Trans. A 2018, 49, 6215-6223. [CrossRef]

35. Wallach, E.R.; Davies, G.J. Mechanical properties of aluminium-copper solid-phase welds. Met. Technol. 1977, 4, 183-190. [CrossRef]

36. Chen, C.Y.; Chen, H.L.; Hwang, W.S. Influence of Interfacial Structure Development on the Fracture Mechanism and Bond Strength of Aluminum/Copper Bimetal Plate. Mater. Trans. 2006, 47, 1232-1239. [CrossRef]

37. Doerner, M.F.; Nix, W.D. A method for interpreting the data from depth-sensing indentation instruments. J. Mater. Res. 1986, 1, 601-609. [CrossRef]

38. Murray, J.L. The aluminium-copper system. Int. Met. Rev. 1985, 30, 211-233. [CrossRef]

39. Prince, A.; Hari Kumar, K.C. Al-Cu-Ni (Aluminium-Copper-Nickel). In Light Metal Systems. Part 2; Effenberg, G., Ilyenko, S., Eds.; SpringerMaterials: Stuttgart, Germany, 2005; pp. 1-23.

40. Rouxel, T.; Laurent, Y. Fracture characteristics of SiC particle reinforced oxynitride glass using chevron-notch three-point bend specimens. Int. J. Fract. 1998, 91, 83-101. [CrossRef]

41. Serbena, F.C.; Souza, G.P.; Zanotto, E.D.; Lumeau, J.; Glebova, L.; Glebov, L.B. Internal Residual Stresses in Partially Crystallized Photo-Thermo-Refractive Glass. J. Am. Ceram. Soc. 2011, 94, 671-674. [CrossRef]

42. Serbena, F.C.; Mathias, I.; Foerster, C.E.; Zanotto, E.D. Crystallization toughening of a model glass-ceramic. Acta Mater. 2015, 86, 216-228. [CrossRef]

43. Khan, R.M.A.; Ahmed, B.A.; Malki, M.M.A.; Hakeem, A.S.; Laoui, T. Synthesis of hard and tough calcium stabilized $\alpha$-sialon/SiC ceramic composites using nano-sized precursors and spark plasma sintering. J. Alloys Compd. 2018, 757, 200-208. [CrossRef] 